\title{
Surgical treatment of emphysematous bullae: late outcome
}

\author{
MG PEARSON, COLIN OGILVIE \\ From the Liverpool Regional Cardiothoracic Centre, Broadgreen Hospital, Liverpool
}

ABSTRACT From 1967 to 197212 patients were operated on for emphysematous bullae in the Liverpool regional cardiothoracic centre. The patient with the poorest lung function died in the immediate postoperative period but the remainder survived for more than five years. All but on $\overrightarrow{\omega_{j}}$ of the survivors showed evidence of benefit three to six months after surgery and all those not retired returned to full-time employment for at least five years. Nine patients were reviewed 5-1 $\bar{\theta}$ years after surgery. These all reported a gradual return of dyspnoea, which was matched by an falling one-second forced expiratory volume $\left(\mathrm{FEV}_{1}\right)$ (mean fall $82 \mathrm{ml}$ a year); but five were sti尔 maintaining some of their postoperative improvement. When mean preoperative lung function values were compared with the values obtained 5-10 years later there was still a significant improvement in forced vital capacity; but $\mathrm{FEV}_{1}$, residual volume, transfer coefficient, and arteria oxygen and carbon dioxide tensions were unchanged. Chest radiographs showed no new bullae ơp (except in one case) any increase in size of pre-existing bullae.

We conclude that the removal of large emphysematous bullae did not hasten the progress of the underlying emphysema and that in most patients some benefit lasted for more than five years after the operation. Patients treated by lobectomy fared at least as well as those treated b\% bullectomy alone. It may be relevant to the relatively good progress of patients in this series that only three had suffered from chronic bronchitis before operation or smoked after operation, a $\overrightarrow{\mathrm{A}}$ but two had bullae occupying half or more of one hemithorax, and none had hypercapnia.

The indications for resection of bullae and the immediate benefits of the procedure are well known. ${ }^{2}$ Information about the long-term outcome is more scanty and conflicting. This report describes the outcome in a small group of patients operated on in the Liverpool regional cardiothoracic centre during a five-year period and followed up for 5-10 years.

\section{Patients and methods}

From 1967 to 197213 operations for the removal of emphysematous bullae were carried out on 12 patients in this unit. The clinical details of these patients are shown in table 1 . The patients were all men, with a mean age of 54 years. All smoked cigarettes but only three had evidence of chronic bronchitis. All were dyspnoeic (grade 3 or more in

Address for reprint requests: Dr MG Pearson, Liverpool Regional Cardiothoracic Centre, Broadgreen Hospital, Liverpool L14 3LB. nine patients), with a reduced forced expiratory vo $\vec{E}$ ume in one second $\left(\mathrm{FEV}_{1}\right)$ (mean $1.191,40 \%$ pre dicted). Mean preoperative values for forced vit capacity (FVC), $\mathrm{FEV}_{1}$, and dyspnoea grade are. shown in table 2 and values for residual volumie (RV), transfer coefficient for carbon monoxide $(\mathrm{KCO})$, and arterial gas tensions $\left(\mathrm{PaO}_{2}\right.$ and $\left.\mathrm{PaCO}_{2}\right)$ in table 3. In most patients the RV was increased and the $\mathrm{KCO}$ and $\mathrm{PaO}_{2}$ were reduced, but the $\mathrm{PaCO}_{2}$ wass normal in every patient.

The preoperative and postoperative investigations were all carried out in the same laboratory and by the same techniques. These included clinical examiv nation, dyspnoea grading on a five-point scale chest radiographs taken in inspiration and expira tion, FVC and FEV 1 measured by a standard low:resistance water spirometer, subdivisions of the lung volume determined by the helium-dilution technique and $\mathrm{KCO}$ by the single-breath carbon monoxide method, and arterial blood gas tensions measuret with an IL 403 Blood Gas analyser. Statistical con parisons were made with the paired Student's $t$ tesf: 
Table 1 Clinical features of the 12 patients and operative findings

\begin{tabular}{|c|c|c|c|c|c|c|c|c|}
\hline 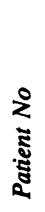 & $\stackrel{\infty}{\infty}$ & 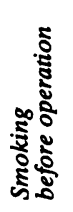 & 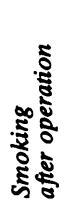 & 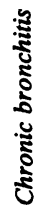 & 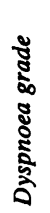 & 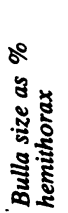 & Operative findings & Operation \\
\hline $\begin{array}{l}1 \\
2 \\
3\end{array}$ & $\begin{array}{l}52 \\
58 \\
58\end{array}$ & $\begin{array}{l}+ \\
+ \\
+\end{array}$ & + & + & $\begin{array}{l}2 \\
2 \\
3\end{array}$ & $\begin{array}{l}20 \\
80 \\
50\end{array}$ & $\begin{array}{l}15 \mathrm{~cm} \text { bulla LLL, several smaller bullae LUL } \\
\text { Large bulla in LUL, rest of lung emphysematous } \\
\text { Large multilocular bulla in LLL, LUL compressed, } \\
\text { small bullae in LUL }\end{array}$ & $\begin{array}{l}\text { Bullectomy over-sewing } \\
\text { Bullectomy } \\
\text { Bullectomy over-sewing }\end{array}$ \\
\hline 4 & 49 & + & & & 3 & 50 & $\begin{array}{l}\text { Large bulla LUL anteriorly, rest of lung } \\
\text { emphysematous }\end{array}$ & Bullectomy \\
\hline 5 & 44 & + & & & 2 & 70 & $\begin{array}{l}\text { One large and many small bullae RUL, } \\
\text { RLL emphysematous }\end{array}$ & Upper lobectomy \\
\hline 6 & 52 & + & + & + & 5 & 75 & $\begin{array}{l}\text { LLL replaced by one large bulla, } \\
\text { LUL emphysematous }\end{array}$ & Lower lobectomy \\
\hline $\begin{array}{l}7 \\
8\end{array}$ & $\begin{array}{l}68 \\
43\end{array}$ & $\begin{array}{l}+ \\
+\end{array}$ & & + & $\begin{array}{l}5 \\
4\end{array}$ & $\begin{array}{l}50 \\
50\end{array}$ & $\begin{array}{l}\text { Large bulla replacing LLL, LUL of poor texture } \\
\text { LUL many large bullae, LLL emphysematous, } \\
\text { RUL huge tense bulla, RLL and } \\
\text { RML emphysematous }\end{array}$ & $\begin{array}{l}\text { Lower lobectomy } \\
\text { Staged upper lobectomies }\end{array}$ \\
\hline 9 & 43 & + & & & 3 & 60 & $\begin{array}{l}\text { RLL one large and many small bullae, RML cystic, } \\
\text { RUL no bullae but emphysematous }\end{array}$ & $\begin{array}{l}\text { Middle and lower } \\
\text { lobectomy }\end{array}$ \\
\hline 10 & 57 & + & & & 3 & 60 & $\begin{array}{l}\text { Two large bullae RLL, RML and RUL collapsed } \\
\text { except for few bullae }\end{array}$ & Lower lobectomy \\
\hline 11 & 70 & + & & & 5 & 40 & Multiple bullae RLL compressing RUL and RML, & Lower lobectomy \\
\hline 12 & 51 & + & & & 5 & 50 & Large bullae LUL, multiple smaller bullae LLL & Bullectomy over-sewing \\
\hline
\end{tabular}

LLL, LUL - left lower and upper lobe; RLL, RML, RUL - right lower, middle, and upper lobe.

\section{Results}

All 12 patients were traced and nine returned for review from five to 10 years after the operation. Of the remaining three, one (No 12) had died of bronchopneumonia in the immediate postoperative

Table 2 Changes mean ( $\pm 1 S D$ ) in FVC, FEV, and dyspnoea grade of the 11 survivors

\begin{tabular}{|c|c|c|c|}
\hline & \multirow[t]{2}{*}{ Before operation } & \multicolumn{2}{|l|}{ After operation } \\
\hline & & $3-6 m$ & $5-10 y$ \\
\hline FVC (l) & $2.29 \pm 0.68$ & $2 \cdot 84 \pm 0.37^{*}$ & \multirow{3}{*}{$\begin{array}{l}2.81 \pm 0.45^{*} \\
\text { NS } \\
1.33 \pm 0.67 \\
\text { NS } \\
2.80 \pm 1.8\end{array}$} \\
\hline $\mathrm{FEV}_{1}(\mathrm{l})$ & $1.19 \pm 0.55$ & $1.77 \pm 0.33^{* *}$ & \\
\hline $\begin{array}{c}\text { Dyspnoea } \\
\text { grade }\end{array}$ & $3.45 \pm 1.2$ & $1.60 \pm 0.7^{* *}$ & \\
\hline
\end{tabular}

Improvement over preoperative value: ${ }^{*} p<0.01 ;{ }^{* *} p<0.001$.

Table 3 Changes in mean $( \pm 1 S D)$ residual volume $(R V)$, transfer coefficient (KCO), and arterial gas tensions

\begin{tabular}{lcc}
\hline & Before operation & $5-10$ y after operation \\
\hline $\mathbf{R V}(1)(\%$ predicted) & $2.8 \pm 1.1(142)$ & $2.8 \pm 0.7(132)$ \\
$\mathrm{Kco}_{(\mathrm{ml} \mathrm{min}}{ }^{-1}$ & $3.5 \pm 1.5$ & $3.1 \pm 1.6$ \\
$\mathrm{mmHg}^{-1} \mathrm{1}^{-1}$ & $10.1 \pm 0.9$ & $10.2 \pm 1.3$ \\
$\mathrm{PaO}_{2}(\mathrm{kPa})$ & $4.9 \pm 0.5$ & $5.2 \pm 0.2$ \\
$\mathrm{Paco}_{2}(\mathrm{kPa})$ &
\end{tabular}

Conversion: Sl to traditional units - Blood gases: $1 \mathrm{kPa}=7.5 \mathrm{~mm}$ $\mathrm{Hg}$. period, one (No 5) was alive and working 10 years after surgery but refused to attend for review, and the third (No 10) died of a myocardial infarct eight years after the operation. This last patient had been followed up regularly at another hospital and was recorded as being well and free of dyspnoea only one month before his death.

Apart from the patient who died in the postoperative period, all patients survived for at least five years after the operation (mean survival at time of follow up 7.3 years). All but one reported symptomatic benefit when seen three to six months after surgery and this was reflected in the improved FVC and $\mathrm{FEV}_{1}$ (table 2). Apart from the two patients already retired and the one who died, all patients returned to work and remained in full-time employment for at least five years.

Over the years dyspnoea tended to return and the FEV , to fall; at the time of follow-up four of the nine were virtually back to their preoperative level, though five were still maintaining some of their postoperative improvement (fig). The mean decline in the FEV, was $82 \mathrm{ml}$ a year. On the other hand the postoperative improvement in FVC was well sustained. The mean values for FVC, $F_{1}$, and dyspnoea grading before and after surgery are shown in table 2. There was significant improvement in all three measurements in the early postoperative period, but at 5-10 years only the FVC improvement is significant. Linear regression analysis shows 


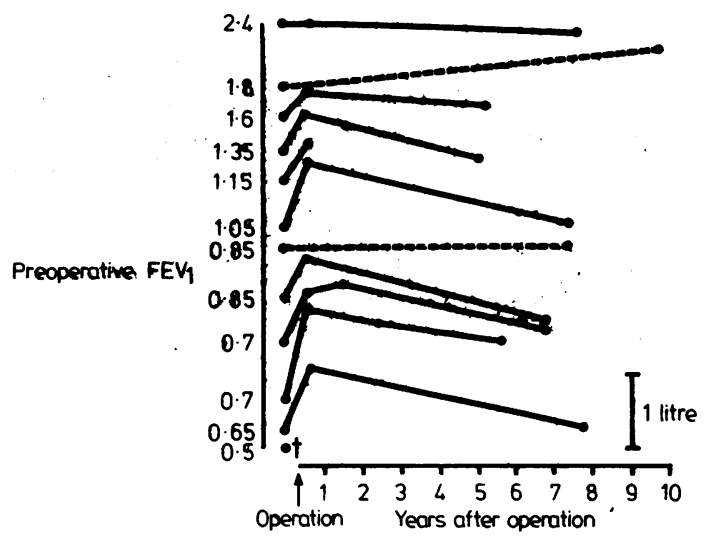

Serial changes in $F E V$, for the 12 patients in descending order of preoperative FEV (same order as table 1).

Table 4 Changes in residual volume (l) in three patients

\begin{tabular}{llll}
\hline Patient No & Before operation & \multicolumn{2}{l}{ After operation } \\
\cline { 3 - 4 } & & $3-6 m$ & $5-10 y$ \\
\hline 3 & 1.75 & 1.4 & 2.35 \\
4 & 3.5 & 2.25 & 3.35 \\
8 & 3.75 & 2.4 & 3.0 \\
Mean \% & & & \\
predicted & 159 & 106 & 146 \\
\hline
\end{tabular}

an inverse correlation between $\mathrm{FEV}_{1}$ and dyspnoea grade $(\mathrm{r}=-0.79, \mathrm{p}=<0.01)$.

$\mathrm{RV}, \mathrm{KCO}$, and blood gases were measured before surgery and at follow up 5-10 years later in eight patients. There was no significant difference between the values obtained on these two occasions (table 3). RV fell, however, in the early postoperative period in the three patients for whom measurements were available (table 4).

Chest radiographs were available for 10 patients 5-10 years after the operation. None showed new bullae on the operated side and only one (No 4) showed an increase in size of a pre-existing contralateral bulla.

\section{Discussion}

Previous authors have agreed that early postoperative results are good when large bullae are removed, ${ }^{12}$ and the $\mathrm{FEV}_{1}$ has been regarded as the most reliable guide to postoperative progress. ${ }^{4-6}$ The present study supports these observations. The one patient with a bulla occupying less than a third of the hemithorax was the only one to show no symptomatic or objective improvement, and in the series as a whole there was a highly significant inverse correlation between dyspnoea grade ang FEV .

There are few published accounts of the bonges term outcotpe of surgery. Fitzgerald and others prof. sent spinometric data on 15 similar patients follow for mope than three years (eight for more than fige years) and found a pattern similar to the one we describe but with an amanal decliec to $\mathrm{FEV}_{\mathbf{l}} \overrightarrow{\text { of }}$ $101 \mathrm{ml} .5$ Wesley and others reported throe five-year survivors but three of the 11 followed for shorter pertods had already died. 6 Pride and others foung evidence of benefit two to three years after surgery in only three of their 10 patients. ${ }^{4}$ The meen preoperative $F E V_{1}$ in this last series was lower that in any of the others and the mean postoperative increase in $\mathrm{FEV}_{1}(1.041$ to 1.241$)$ was considerably less than in our series (1.19-1.77 1).

The mean annual decline in $\mathrm{FEV}_{1}$ of $82 \mathrm{md}$ in ouf patients is similar to that reported in large series off patients with chronic obstructive airways disease $\left(80-90 \mathrm{ml}\right.$ a year)..$^{78}$ This suggests that removal 得 large bullae does not hasten the progression of emphysema in the remaining lung, a view supporteg by the fact that no new bullae appeared in the postoperative radiographs.

The relatively good postoperative progress of ofr patients, with all but three of the survivors still sho ing objective evidence of benefit (in FVC or FEV) more than five years after surgery, may of course relate to preoperative selection and to operatice procedure. With regard to selection only three patients had significant sputum production, nope had a raised $\mathrm{PaCO}_{2}$, and all but two had bullae occupying one half or more of the hemithorax. Twe of the three with no objective evidence of benent five to ten years after operation were the on patients who had chronic bronchitis before operation and smoked after it (Nos 1 and 6). Half the patients had a preoperative $\mathrm{FEV}_{1}$ of less than a lit\&e but the only patient with an $\mathrm{FEV}_{1}$ of less than 0.5 litres died in the immediate postoperative period?

Seven patients were treated by lobectomy and five by bullectomy. It has been suggested ${ }^{15}$ that patien with disease extensive enough to require lobectomy do not fare so well as those in whom bullectomy-is performed. The seven patients treated by lobecton in this series all had more extensive disease and poorer preoperative lung function than four of the five treated by bullectomy but there was no diffeence in the long-term outcome of the two groups. Indeed, the only death was in the bullectomy grous, which also contained two of the three survivors showing no objective evidence of benefit at followup.

We wish to thank the surgeons past and present 
the Liverpool regional cardiothoracic unit for their important contribution to the work described in this paper, Mrs Doreen Russell and her staff for technical assistance, and Mrs Barbara Mann for typing the manuscript.

\section{References}

' Potgieter PD, Benator SR, Hewitson RP, Ferguson AD. Surgical treatment of bullous lung disease. Thorax 1981;36:885-90.

${ }^{2}$ Hugh-Jones $P$, Whimster W. The etiology and management of disabling emphysema. Am Rev Respir Dis 1978;117:343-78.

${ }^{3}$ Fletcher CM, Elmes PC, Fairburn AS, Wood CH. The significance of respiratory symptoms and the diagnosis of chronic bronchitis in a working population. $\mathrm{Br}$ Met J 1959; :1: 257-66.

4 Pride NB, Hugh-Iones P, O'Brien EN, Smith LA. Changes in lung function following the surgical treatment of bullous emphysema. $Q J$ Med 1970;153:49 69.

${ }^{5}$ Fitzgerald MX, Keelan PJ, Gaensler EA. Long-term results of surgery for bullous emphysema. $J$ Thorac Cardiovasc Surg 1974;68:566-87.

- Wesley JR, Macleod WM, Mullard KS. Evaluation of surgery in bullous emphysema. $J$ Thorac Cardiovasc Surg 1972;63:945-55.

${ }^{7}$ Jones NL, Burrows B, Fletcher CM. Serial studies of 100 patients with chronic obstructive lung disease in London and Chicago. Thorax 1967;22:327-35.

${ }^{8}$ Burrows B, Earle RH. Course and prognosis of chronic obstructive lung disease. N Eng J Med 1969;280:397-404. 